\title{
HUBUNGAN TINGKAT STRESS DENGAN KUALITAS TIDUR PADA MAHASISWA TINGKAT AKHIR UNIVERSITAS BHAKTI KENCANA
}

\author{
${ }^{1}$ Anri \\ ${ }^{2}$ Manaf \\ ${ }^{3}$ Lulu \\ ${ }^{1}$ Universitas Bhakti Kencana Bandung \\ ${ }^{2}$ Sekolah Tinggi Manajemen IMMI Jakarta \\ ${ }^{3}$ Universitas Bhakti kencana Bandung \\ email: anri@bku.ac.id
}

\begin{abstract}
ABSTRAK
Pendahuluan: Perguruan tinggi yaitu jenjang pendidikan setelah sekolah menengah pertama yang mencakup program pendidikan D III, S-1, S-2, spesialis dan S-3 yang diselenggarakan oleh perguruan tinggi. Salah satu kehidupan akademik yang dapat menjadikan stres pada mahasiswa mahasiswa merupakan adanya perubahan gaya belajar dari sekolah menengah Atas ke perguruan tinggi, begitu juga adanya tugas-tugas kuliah yang harus di selesaikan, adanya target pencapaian nilai yang harus di kejar, terutma stres pada mahasiswa semester akhir yaitu untuk membuat tugas akhir karya ilmiah atau skripsi. Metode: Jenis penelitian yang digunakan deskriptif korelasi yang bersifat mencari hubungan antara kedua fenomena atau lebih, dan menggunakan pendekatan Cross sectional dengan sampel sebanyak 62 orang dengan tehnik stratified random sampling. Metode pengumpulan data menggunakan data menggunakan data primer dengan menyebarkan kuesioner yang dibagikan dan di isi oleh mahasiswa yang sedang mengerjakan karya tulis ilmiahnya di Universitas Bhakti Kencana Prodi D III Keperawatan. Kuesioner yang di gunakan menggunakan kuesioner yang sudah baku yaitu yang di adopsi dari kuesioner Safira dan Safutra (2009) mengenai tingkat stres. Kuesioner tersebut di modifikasi oleh peneliti dengen menggunakan Bahasa yang mudah di pahami, jelas sesuai dengan keadaan sampel yaitu mahasiswa tingkat akhir yang sedang mengerjakan karya tulis ilmiah. Hasil: Hasil analisis hubungan tingkat stres dengan gangguan kualitas tidur didapatkan nilai p-value $(0.004)<$ dari nilai alpha (0.05) sehingga $\mathrm{H}_{0}$ ditolak $\mathrm{H}_{1}$ diterima Kesimpulan: terdapat hubungan yang signifikan antara tingkat stres dengan ganguan kualitas tidur pada mahasiswa prodi D III Yang sedang melakukan KTI.
\end{abstract}

Kata Kunci: Tingkat setres ; Kualitas tidur pada mahasiswa covid -19 


\begin{abstract}
Introduction: Higher education is the level of education after junior high school which includes D III, S-1, S-2, specialist and S-3 education programs organized by universities. One of the academic life that can cause stress to students is a change in learning styles from high school to college, as well as college assignments that must be completed, there is a target achievement value that must be pursued, especially stress on semester students. The final task is to make the final project of a scientific paper or thesis. Methods: The type of research used is descriptive correlation which is looking for a relationship between two or more phenomena, and uses a cross sectional approach with a sample of 62 people with stratified random sampling technique. The data collection method used primary data by distributing questionnaires that were distributed and filled in by students who were working on their scientific papers at Bhakti Kencana University, D III Nursing Study Program. The questionnaire used was a standardized questionnaire, which was adopted from the Safira and Safutra (2009) questionnaire regarding stress levels. The questionnaire was modified by the researcher by using language that is easy to understand, clearly in accordance with the state of the sample, namely final year students who are working on scientific papers. Results: The results of the analysis of the relationship between stress levels and sleep quality disorders obtained a p-value (0.004) < from the alpha value (0.05) so that HO was rejected, H Kesimpulan was accepted. Conclusion: there is a significant relationship between stress levels and sleep quality disorders in D III study program students. doing KTI.
\end{abstract}

Keywords: stress level ; sleep quality in covid-19 students mahasiswa

\section{PENDAHULUAN}

Gaya pembelajaran di PT berbeda dengan SMA dan memiliki tuntutan yang berbeda. tuntutan dari akademik yang di hadapi mahasiswa akan menjadi stressor bagi mahasiswa, stressor dari dalam maupun dari luar diri mahasisiwa ( Lubis 2010)

Perbedaan dari siswa menjadi mahasiswa yang memiliki lebih banyak kebebsan untuk mengatur dirinya dalam belajar (Hartaji, 2012). Mahasiswa dalam menyelesaikan akademiknya selalu di hadapkan pada kondisi ujian terutama pada mahasiwa tingkat akhir akan menghadapi tugas akhir yaitu sekripsi (robotham, 2008) Kehidupan akademik yang bisa menimbulkan stres bagi mahasiswa yaitu perubahan metode pembelajaran dari SMA ke PT, tugas - tugas kuliah, pencapaian target prestasi dan dan kebutuhan untuk mengatur hidup diri sendiri dan mengembangkan kemampua berpikir yang lebih baik (Fadillah, 2013 dalam witrin 2018). Terutma stres pada mahasiswa semester akhir yaitu untuk membuat tugas akhir karya ilmiah atau skripsi (Fadillah, 2013 dalam wirtin, 2018).

Stres adalah salah suatu keadaan disebabkan oleh fisik, lingkungan, dan situasi sosial yang tidak terkontrol. WHO mengatakan hamper mencapai 350 juta lebih masyarakat di dunia mengalami stres dan menempati urutan ke 4 di dunia. Hasil penlitian stres yang dilakukan oleh Health and Safety Executive di Inggris melibatkan penduduk Inggris sebanyak 487.000 orang yang masih produktif dari tahun 2013-2014. Dilihat dari jenis kelamin wanita lebih banyak $(54,62 \%)$.

Berbagai penelitian yang sudah dilakukan di fakultas dan di beberapa universitas di dunia 
Vol.3.No 1 (2021)

p-ISSN :2657-2435

e-ISSSN:2721-3145

tentang setres pada mahasiswa. Data mahasiswa yang mengalami stres di dunia sebesar 38-71\%, dibandingkan dengan di Asia sebesar 39,6-61,3\% (Habeeb 2010, Koochaki 2009). Sementara itu, prevalensi mahasiswa yang mengalami stres di Indonesia sendiri didapatkan sebesar 36,771,6\% (Fitasari 2011).

Hal ini sejalan dengan penelitian lubis dan nurmala (2020) dia mengatakan bahwa tingkat stres yang tejadi pada mahasiswa sangat eningkat lima kali lebih tinggi dibandingkan kejdian stress pada remaja pada tahun 1938. Begitu juga hasi penelitian lema dkk (2012) hasil yang di peroleh 0,8\% $(1,294)$ mahasiswa amemiliki gejala deoeresi, 58\% (1.369) mahasiswa memiliki gejala kecemasan dan 34,1\% (864) mahasiswa memiliki gejala stress, , 55,8\% $(1,424)$ mahasiswa memiliki kualitas tidur buruk jika dibandingkan dengan mahasiswa tikta 2 an tiangkat 1 .

Tidur merupakan suatu kebutuhan yang dasar bagi setia manusia, Henderson mengatakan bahwa istirahat tidur merupakan termasuk ke daftar 14 kebutuhan manusia yaitu pernapasan, kebutuhan makan, eliminasi istirahat, kebutuhan berpakaian, kebutuhan pertahanan suhu tubuh dan lingkungan, kebersihan tubuh, kondisi lingkungan, berkomunikasi, beribadah dan keyakinan dan rekreasi dan juga kebutuhan belajar dan kebutuhan dalam menggunakan pelayanan fasilitas Kesehatan (Wilkinsons, 2011)

Stress salah satu penyebab dari gangguan tidur karena pada saat Ketika stress adanya peningkatan hormone epineprin, norepineprin dan juga koristol yang akan mempengaruhi susunan saraf pusat dan akan menimbulkan peningkatan kepwasoadaan system saraf pusat hal tersebut juga akan mempengaruhi kualitas individu,dan selain perubahan hormone juga dapat mempengaruhi siklus tidur NREM dan REM sehingga membuat orang akan sering terbangun pada saat malam harridan akan bermimpi buruk (Sherwood, 2011).

Hasil studi pendahuluan yang dilakukan peneliti pada mahasiswa yang mau menghadapi tugas akhir terjadi pada mahasiswa Fakultas keperawatan Prodi D III Keperawatan yaitu berkeluh kesah, pusing, terlihat cemas dan tidak bersemangat, ketika mengalami kendala dalam menyelesaikan KTI. yang terjadi akibat stres juga akan berdampak sengaja tidak mengerjakan Tugas Khirnya karena tidak mau merasa terbebani sehingga lebih memilih mencari kesenangan dari kegiatan lain di luar kampus dan menghindari dosen pembimbing.

Akibat dampak stres yang tidak ringan, perlu ada teknik yang tepat untuk mengurangi atau mengalihkan atau menghiangkan dampak stres tersebut. Berdasarkan penelitian (Sugiarto, 2012) ditemukan hasil adanya hubungan positif antara kecerdasan emosi dengan daya tahan mahasiswa terhadap stres.

Berdasarkan hasil wawancara yang dilakukan pada mahasiswa tingkat akhir di Universitas Bhakti Kencana, mahasiswa juga mengalami dampak stres. Dampak positif dari stres yang dialami mahasiswa seperti, meningkatkan kreativitas dan menjadikan. Tujuan dilakukan penelitian ini untuk mengetahui hubungan tingkat stress dengan kualitas tidur pada mahasiswa tingkat akhir universitas bhakti kencana 


\section{METODE PENELITIAN}

Rancangan penelitian yang digunakan yaitu deskriptif korelasi yang bersifat mencari gubungan antara kedua fenomena atau lebih, dan menggunakan pendekatan Cross sectional yaitu suatu penelitian dimana variable-variabel yang termasuk faktor resiko dan variable yang termasuk efek diteliti sekaligus pada waktu yang bersamaan (Sutriyawan, 2021).

Penelitian ini dilakukan pada mahasiswa keperawatan universitas haktikencana prodi D III Keperawatan yang sedang melakukan tugas akhir karya tulis ilmiah. Teknik pengambilan sampel pada penelitian ini menggunakan pengambilan secara simple random sampling yaitu setiap anggota atau unit dari populasi mempunyai kesempatan yang sama untuk diseleksi sebagai sampel (Notoatmodjo,2010).

Penelitian ini mengacu pada Penelitian tingkat stres dengan kejadian insomnia pada mahasiswa yang sedang mengerjakan tugas akhir di universitas Bhakti Kencana Penelitian ini lebih memfokuskan pada tingkat stres denga kejadian insomnia sebagai upaya meningkatkan bimbingan yang mengurangi stres mahasiswa di Universitas Bhakti Kencana Prodi D III keperawatan.

Prosedur pelaksanaan Penelitian tingkat stress terhad gangguan tidur dengan cara pengumpulan data menggunakan data primer dengan menyebarkan kuesioner yang dibagikan dan di isi oleh mahasiswa yang sedang mengerjakan karya tulis ilmiahnya di Universitas Bhakti Kencana Prodi D III Keperawatan. Kuesioner yang di gunakan menggunakan kuesioner yang sudah baku yaitu yang di adopsi dari kuesioner Safira dan Safutra (2009) mengenai tingkat stres. Kuesioner tersebut di modifikasi oleh peneliti dengen menggunakan Bahasa yang mudah di pahami, jelas sesuai dengan keadaan sampel yaitu mahasiswa tingkat akhir yang sedang mengerjakan karya tulis ilmiah.

Analisis yang di gunakan pada penelitian ini adalah analisis univariat dan analisis bivariat. Tujuan dari analisis univariat yaitu untuk menjelasakan distribusi tingkat stres dan kejadian insomnia sedangkan analisis bivariat untuk mengetahui pengaruh tingkat stres dengan kejadian insomnia pada mahasiswa yang sedang mengerjakan karya tulis ilmiah.

\section{HASIL DAN PEMBAHASAN}

Tabel 4.1 Distribusi jenis kelamin Mahasiswa Tingkat Akhir Universitas Bhakti Kencana

\begin{tabular}{lll}
\hline Jenis Kelamin & $\mathrm{F}$ & $\%$ \\
\hline Laki-Laki & 13 & 21.0 \\
Perempuan & 49 & 79.0 \\
\hline Total & 62 & 100.0 \\
\hline
\end{tabular}

Dari Tabel 4.1 hasil analisis univariat tentang jenis kelamin mahasiswa tingkat akhir yang sedang melakukan karya tulis ilmiah di saat pandemi di Fakultas Keperawatan Prodi D III Keperawatan Universitas Bhakti Kencana diatas menunjukan bahwa Sebagian responden 49 $(79,0 \%)$ berjenis kelamin perempuan dan sebagain kecil berjenis kelamin $13(21,0)$.

Tabel 4.2 Distribusi Frekuensi Status Tingggal Mahasiswa Tingkat Akhir Universitas Bhakti Kencana

\begin{tabular}{lll}
\hline Status tinggal & F & $\%$ \\
\hline Lain-Lain & 3 & 4.8
\end{tabular}




\begin{tabular}{|c|c|c|c|}
\hline $\begin{array}{l}\text { Bersama } \\
\text { Tua }\end{array}$ & Orang & 48 & 77,4 \\
\hline Kost & & 11 & 17.7 \\
\hline Total & & 62 & 100.0 \\
\hline
\end{tabular}

Tabel 4.2 hasil analisis univariat tentang statustinggal mahasiswa tingkat akhir yang sedang melakukan karya tulis ilmiah di saat pandemi di Fakultas Keperawatan Prodi D III Keperawatan Universitas Bhakti Kencana diatas menunjukan bahwa Sebagian responden $48(77,4 \%)$ tinggal Bersama orang tua, sebagain status tinggal $11(17,7)$ dan sangat sedikit responden $3(4.8 \%)$ status tinggal lain-lain

Tabel 4.3

Distribusi Frekuensi Aktifitas Selain Kuliah Mahasiswa Tingkat Akhir Universitas Bhakti Kencana

\begin{tabular}{|c|c|c|}
\hline $\begin{array}{l}\text { Aktifitas Selain } \\
\text { Kuliah }\end{array}$ & $\mathrm{F}$ & $\%$ \\
\hline Lain-Lain & 38 & 61,3 \\
\hline Olah raga & 13 & 21.0 \\
\hline Organisasi & 3 & 4.8 \\
\hline $\begin{array}{l}\text { Kerja } \\
\text { Freelance/Fulltime }\end{array}$ & 8 & 12,9 \\
\hline Total & 62 & 100.0 \\
\hline
\end{tabular}

Dari Tabel 4.3 hasil analisis univariat tentang aktifitas selain kuliah mahasiswa tingkat akhir yang sedang melakukan karya tulis ilmiah di saat pandemi di Fakultas Keperawatan Prodi D III Keperawatan Universitas Bhakti Kencana diatas menunjukan bahwa Sebagian responden 38 $(61,3 \%)$ aktidfitas selain kuliah lain-lain, Sebagian kecil 13 (21.0\%) aktifitas selain kuliah olah raga sedikit responden $8(12,9 \%)$ aktifitas selain kuliah kerja freelance/fultime dan sangat sedikit responden $3(4,8 \%)$ aktifitas selain kuliah organisasi.
Tabel 4.4 Distribusi Frekuensi Tingkat stres Pada Mahasiswa Tingkat Akhir Universitas Bhakti Kencana

\begin{tabular}{lll}
\hline Tingkat stress & F & $\%$ \\
\hline Stres Ringan & 29 & 46,8 \\
Stres Sedang & 28 & 45,2 \\
Stres Berat & 5 & 8,1 \\
\hline Total & 62 & 100.0 \\
\hline
\end{tabular}

Dari Tabel 4.4 hasil analisis univariat tentang tingkat stres mahasiswa tingkat akhir yang sedang melakukan karya tulis ilmiah di saat pandemi di Fakultas Keperawatan Prodi D III Keperawatan Universitas Bhakti Kencana diatas menunjukan bahwa Sebagian responden 29 $(46,8 \%)$ tingkat stres ringan, Sebagian 28 $(45,2 \%)$ tingkat stres sedang dan sangat sedik sekali responden $5(8,1 \%)$ tingkat stres berat.

Tabel 4.5 Distribusi Frekuensi Kualitas Tidur Pada Mahasiswa Tingkat Akhir Universitas Bhakti Kencana

\begin{tabular}{|c|c|c|c|}
\hline Kualitas & & $\mathrm{F}$ & $\%$ \\
\hline $\begin{array}{l}\text { Kualitas } \\
\text { baik }\end{array}$ & tidur & 28 & 45.2 \\
\hline $\begin{array}{l}\text { Kualitas } \\
\text { Buruk }\end{array}$ & Tidur & 34 & 54.8 \\
\hline Total & & 62 & 100.0 \\
\hline
\end{tabular}

Dari Tabel 4.5 hasil analisis univariat tentang kualitas tidur mahasiswa tingkat akhir yang sedang melakukan karya tulis ilmiah di saat pandemi di Fakultas Keperawatan Prodi D III Keperawatan Universitas Bhakti Kencana diatas menunjukan bahwa Sebagian responden 28 $(45,2 \%)$ kualitas tidur aik, dan sebagian besar responden $34(54,8 \%)$ kualitas tidur buruk 
e-ISSSN:2721-3145

Tabel 4.6 Hubungan Tingkat Stres Dengan Gangguan Kualitas Tidur Pada Mahasiswa Tingkat Akhir Universitas Bhakti Kencana

\begin{tabular}{|c|c|c|c|c|c|c|c|c|}
\hline \multirow{3}{*}{ Tingkat Stres } & \multicolumn{4}{|c|}{ Kualitas Tidur } & \multirow{2}{*}{\multicolumn{2}{|c|}{ Total }} & \multirow{3}{*}{ P-Value } & \multirow{3}{*}{$\mathbf{C}$} \\
\hline & \multicolumn{2}{|c|}{$\begin{array}{c}\text { Kualitas } \\
\text { tidur Baik }\end{array}$} & \multicolumn{2}{|c|}{$\begin{array}{c}\text { Kualitas } \\
\text { Tidur Buruk }\end{array}$} & & & & \\
\hline & $\mathbf{F}$ & $\%$ & $\mathbf{F}$ & $\%$ & $\mathbf{F}$ & $\%$ & & \\
\hline Stres ringan & 19 & 65,5 & 10 & 34,5 & 29 & 46.8 & & \\
\hline Sertres sedang & 9 & 32.1 & 19 & 67,9 & 28 & 45,2 & & \\
\hline Stres berat & 0 & 0.0 & 5 & 14,7 & 5 & 8,1 & 0.004 & 0,386 \\
\hline Total & 28 & 45,2 & 34 & 54,8 & 62 & 100 & & \\
\hline
\end{tabular}

Hasil analisis hubungan tingkat stres dengan gangguan kualitas tidur pada mahasiswa tingkat akhir yang sedang melaksanakan karya tulis ilmiah di saat pandemi di Fakultas Keperawatan Prodi D III Keperawaan Universitas Bhakti Kencana didapatkan nilai $p$-value $(0.004)<$ dari nilai alpha (0.05) sehingga $\mathrm{H}_{0}$ ditolak $\mathrm{H}_{1}$ diterima, dengan demikian ada hubungan tingkat stres dengan gangguan kualitas tidur dan di lihat dari nilai Coeficien Contingensi yaitu 0.386 bahwa hubungan antara tingkat stres dengan gangguan kualitas tidur pada pada mahasiswa tingkat akhir Tingkat keeratan hubungannya adalah rendah

\section{PEMBAHASAN}

\section{Gambaran Tingkat stres Pada} Mahasiswa Tingkat Akhir Universitas Bhakti Kencana

Dari hasil penelitian berupa pengisian kuesioner kepada responden penelitai mendapakan hasil tentang tingkat stres mahasiswa tingkat akhir yang sedang melakukan karya tulis ilmiah di saat pandemi di Fakultas Keperawatan Prodi D III Keperawatan Universitas Bhakti Kencana diatas menunjukan bahwa Sebagian responden $29(46,8 \%)$ tingkat stres ringan, Sebagian $28(45,2 \%)$ tingkat stres sedang dan sangat sedik sekali responden $5(8,1 \%)$ tingkat stres berat.
Mahasiswa dalam penelitian ini bahwa karya tulis ilmiah ini sebagai ancamana yang masih wajar sehingga $\mathrm{n}$ masih mampu untuk mengatasi stresor yang di hadapi selama menyelesaikan karya tulis ilmiah. Hal ini dapat di lihat dari hasil penelitian menunjukan sangat sedikit sekali responden yang mengalami stress berat. Persepsi mahasiswa terhadap stress dapat menjadi dalam penyelesaian karya tulis ilmiah tidak menjadi penghambat untuk melakukan aktivitas lain seperti olahraga, bekerja, atau pun berorganisasi

Hal ini sejalan dengan penelitian lubis dan nurmala (2020) dia mengatakan bahwa tingkat stres yang tejadi pada mahasiswa sangat meningkat lima kali lebih tinggi dibandingkan kejdian stress pada remaja pada tahun 1938. Begitu juga hasi penelitian lema dkk (2012) hasil yang di peroleh $0,8 \%$ $(1,294)$ mahasiswa amemiliki gejala deoeresi, 58\% (1.369) mahasiswa memiliki gejala kecemasan dan 34,1\% (864) mahasiswa memiliki gejala stress, , 55,8\% $(1,424)$ mahasiswa memiliki kualitas tidur buruk jika dibandingkan dengan mahasiswa tikta 2 an tiangkat 1.

Peneliti berasumsi bahwa bahwa mahasiswa yang mengalami stres di sebabkan karena beban kerja atau tuntutan akademik yang 
membuat mahasiswa dituntut untuk meraih target pencpaian yang telah di tentukan oleh pihak kampus maupun oleh mahasiswa itu sendiri. Tuntutan itu sendiridapat berupa metode bimbingan yang berubah karna pandemi yang di gunakan oleh mahasiswa dengan cara konsul online dan pembimbng yang kurang respon sedangkan sekrispsi harus selesai dengan waktu yang telah di tentukan oleh pihak kampus. Beban kerja pada mahasiswa dapat memicu tingkat stres

\section{Gambaran Kualitas Tidur Pada Mahasiswa Tingkat Akhir Universitas Bhakti Kencana}

Dari hasil penelitian berupa pengisian kuesioner kepada responden penelitai mendapakan hasil tentang kualitas tidur mahasiswa tingkat akhir yang sedang melakukan karya tulis ilmiah di saat pandemi di Fakultas Keperawatan Prodi D III Keperawatan Universitas Bhakti Kencana diatas menunjukan bahwa Sebagian responden $28(45,2 \%)$ kualitas tidur baik, dan sebagian besar responden $34(54,8 \%)$ kualitas tidur buruk. responden yang megalmai kualitas tidurnya buruk karena adanya peningkatan stimulus yang di terima oleh retikulea naktiviting system sehinggi hormone katekolamin di sekresi dan membuat responden terjaga atau terbangun begitupun sebaliknya Ketika responden stimulus reticular activating system menurun maka stimulus ke bulbar system reticular meningkat sehingga hormone serotonin disekresi dan menyebabkan responden tidak mengalami gangguan tidur dan Sebagian besar responden mengalami kualitas tidur baik karena Sebagian besar mahasiswa tinggal Bersama orang tua selama mengerjakan karya tulis ilmiah. Mahasiswa yang tinggalnya Bersama orang tua merasa nyaman dengan kondisi fasilitas kamar yang biasa di gunakan untuk tidur seperti tempat tidur. Lua kamar, toilet, ventilasi, dan lain-lain dan selain itu juga mahasiswa telah mengenal lingkungan di sekitar kamarnya sehingga mahasiswa tidak kesulitan untuk beradaptasi dengan perubahan-perubahan di sekitar kamar tidur.

Tidur merupakan suatu kebutuhan yang dasar bagi setia manusia, menurut Henderson tidur dan istirahat memasukan ke dalam daftar empat belas kebutuhan dasar manusia. Yang termasuk ke daftar empat belas kebutuhan dasar manusia adalah pernapasan, kebutuhan makan dan minum, eliminasi kebutuhan tidur dan istirahat, kebutuhan berpakaian, kebutuhan cara mempertahankan suhu tubuh dan memodifikasi lingkungan, kebersihan tubuh, kondisi lingkungan, berkomunikasi, beribadah dan keyakinan dan rekreasi dan juga akebutuhan belajar dan kebutuhan dalam menggunakan fasilitas Kesehatan (Wilkinsons, 2011)

Stress salah satu penyebab dari gangguan tidur karena pada saat Ketika stress adanya peningkatan hormone epineprin, norepineprin dan juga koristol yang akan mempengaruhi susunan saraf pusat dan akan menimbulkan peningkatan kewaspadaan pada SSP (system saraf pusat) hal ini juga dapat mempengaruhi kualitas individu dan selain perubahan pada hormone juga bias mempengaruhi siklus tidur sehingga membuat seseorang akan sering terbangun pada saat malam hari dan akan bermimpi buruk (Sherwood, 2011). 


\section{Hubungan Tingkat Stres Dengan Gangguan Kualitas Tidur Pada Mahasiswa Tingkat Akhir Universitas Bhakti Kencana}

Berdasarkan hasil analisis hubungan tingkat stres dengan gangguan kualitas tidur pada mahasiswa tingkat akhir yang sedang melaksanakan karya tulis ilmiah di saat pandemi di Fakultas Keperawatan Prodi D III Keperawaan Universitas Bhakti Kencana didapatkan nilai p-value $(0.004)<$ dari nilai alpha (0.05) sehingga $\mathrm{H}_{0}$ ditolak $\mathrm{H}_{1}$ diterima, dengan demikian ada hubungan tingkat stres dengan gangguan kualitas tidur dan di lihat dari nilai Coeficien Contingensi yaitu 0.386 bahwa hubungan antara tingkat stres dengan gangguan kualitas tidur pada pada mahasiswa tingkat akhir Tingkat keeratan hubungannya adalah rendah. Hasil penelitian dapat dilihat bahwa mahasiswa yang mengalami tingkat stress ringan $65,5 \%$ kualitas tidurnya baik dan tingkat stresnya sedang paling banyak kulaitas tidurnya buruk.

Pada saat mengalami stres maka akan terjadi peningkatan hormon yaitu hormone epinefrin, norepinefrin, dan kortisol yang mempengaruhi susunan saraf pusat dan menimbulkan keadaan terjaga dan meningkatkan kewaspadaan sistem saraf pusat. Hal ini juga dapat mempengaruhi kualitas tidur individu, selain itu perubahan hormon tersebut juga mempengaruhi siklus tidur Non Rapid Eye Movement (NREM) dan Rapid Eye Movement (REM) maka dari itu dapat membuat orang sering terbangun pada malam hari dan bermimpi buruk (Sherwood , 2011)

\begin{tabular}{lll} 
Mahasiswa & dalam & \multicolumn{2}{c}{ menyelesaikan } \\
akademiknya & selalu di & hadapkan pada \\
kondisi ujian & terutama & pada mahasiwa
\end{tabular} tingkat akhir akan menghadapi tugas akhir yaitu sekripsi (robotham, 2008) Kehidupan akademik yang bisa menimbulkan stres bagi mahasiswa meruakan adanya perubahan gaya belajar dari sekolah menengah Atas ke pendidikan tinggi, tugas - tugas perkuliahan, target pencapaian nilai, prestasi akademik, dan kebutuhan untuk mengatur diri sendiri dan mengembangkan kemampua berpikir yang lebih baik (Fadillah, 2013 dalam witrin 2018). Terutma stres pada mahasiswa semester akhir yaitu untuk membuat tugas akhir karya ilmiah atau skripsi (Fadillah, 2013).

\section{KESIMPULAN}

Berdasarkan hasil penelitian dan pembahasan, maka dapat di tarik suatu kesimpulan sebagai berikut: terdapat hubungan antara tingkat akhir yang sedang melakukan karya tulis ilmiah di saat pandemi di fakultas keperawatan prodi D III keperawatan universitas bhakti kencana

\section{SARAN}

Disarankan kepada mahasiswa tingkat akhir untuk menjaga pola tidur dengan baik dengan cara mengontrol tingkat stress dengan selalu mengkonsumsi makanan bergizi melakukan aktivitas fisik dan pola hiduo sehat

\section{DAFTAR PUSTAKA}

Fadillah, A. E. R. (2013). Stres dan motivasi belajar pada mahasiswa psikologi Universitas Mulawarman yang sedang menyusun skripsi. Ejournal Psikologi Universitas Mulawarman,

Fitasari, isna nur. (2011) factor yang berhubungan dengan kejadian stres pada mahasiswa Fakultas kesehatan masyarakat 
Vol.3.No 1 (2021)

p-ISSN :2657-2435

e-ISSSN:2721-3145

Universitas Airlangga Surabaya : FK airlangga

Notoatmodjo, (2010) Metodologi Penelitian Kesehatan, Jakarta: Rineka Cipta.

Lubis \& Nurlaila (2010) "Mengapa tingkat stres pelajar makin tinggi", Style Sheet: www.vivabews.com/news/read/120642 di unduh tanggal 21 februari 2020

Sherwood, Laura Iee. 2011. Fisiologi Manusia. Jakarta : EGC.

Sugiarto, D (2012). Hubungan kecerdasan dengan daya tahan stress mahasiswa UIN Sunan Kalijaga Yogyakarta

Sutriyawan, A. (2021) Metodologi Penelitian Kedokteran dan Kesehatan: Dilengkapi Tuntunan Membuat Proposal Penelitian. Bandung: PT Refika Aditama. 